TITLE:

\title{
Impact of Postgraduate Education on Physician Practice for Community-acquired Pneumonia(Abstract_要旨 )
}

$\operatorname{AUTHOR}(\mathrm{S})$ :

Ikai, Hiroshi

\section{CITATION:}

Ikai, Hiroshi. Impact of Postgraduate Education on Physician Practice for Communityacquired Pneumonia. 京都大学, 2011, 博士(医学)

ISSUE DATE:

2011-03-23

URL:

http://hdl.handle.net/2433/142078

RIGHT: 


\begin{tabular}{|l|l|c|c|}
\hline 京都大学 & 博士 (医 学 $)$ & 氏 名 & \multicolumn{1}{|c|}{ 猪 飼 宏 } \\
\hline 論文題目 & $\begin{array}{l}\text { Impact of Postgraduate Education on Physician Practice for Community- } \\
\text { acquired Pneumonia } \\
\text { (市中肺炎の診療における卒後教育の影響) }\end{array}$ \\
\hline
\end{tabular}

(論文内容の要旨 $)$

\section{背景}

成人市中肺炎診療ガイドラインは日本で広く認知されている。しかし、医師の ガイドライン遵守状況や患者の転帰に卒後臨床研修が及ぼす効果についてはほ とんど知られていない。

方法

単施設での肺炎入院患者に対する診療録レビューを実施した。実施施設では 2003 年冬から 2005 年冬にかけて、研修医のための教育プログラムが段階的に 導入されており、とりわけ感染症診療に関しては、クラス講義・屋根瓦式指導 ・ ケースカンファレンスを通じた多面的な教育および実地訓練が行われつつあっ た。この研修プログラムの効果を評価するためのプロセス指標として臨床検査 の実施状況・抗菌薬の選択を、またアウトカム指標として抗菌薬投与日数・在 院日数・死亡退院割合を測定した。

\section{結果}

研修プログラム充実の前後を比較すると、次のような点で診療の改善が見られ

（1）血液培養・グラム染色の提出が増加し、喀痰培養や抗酸菌塗沫検査の 実施も増加傾向にあった。

（2）初回選択抗菌薬として、広域抗菌薬の使用が $50 \%$ から $12 \%$ に有意 に減少した。同様に、入院 5 日目時点での広域抗菌薬使用は 6 6.7\%から 1 $0 \%$ に有意に減少した。

（3）在院日数は短縮の傾向にあり、中央值は 16.5 日から 13 日へと変 化した。

なお、総入院医療費については有意な経年変化はなかった。

\section{結論}

グラム染色や培養検查を用いた感染症診断を行い、その結果を踏まえて適切な 治療スペクトラムを備えた抗菌薬を選択し、治療経過に応じた狭域な抗菌薬や 経口薬への適切な変更を行う、といった感染症診療の基本を押さえたプログラ 厶を多面的な教育方法を通じて提供することにより、成人市中肺炎の診療プロ セスはガイドラインにより即したものとなり、臨床アウトカムの改善にもつな がると考えられた。
(論文審査の結果の要旨 $)$

本研究は、一臨床研修指定病院における感染症教育の導入前後にわたる成人市中肺炎 の診療内容の経年的分析を通じて、医師への教育体制の変化が診療内容にもたらした影 響を定量的に明らかにする観察研究である。

感染症教育の経験のある医師の赴任を契機に、グラム染色の実地指導・細菌学的検査 結果に基づく治療方針の検討などの教育を小グループで繰り返し行う体制が整った年の 前年、およびその後 2 年間の合計 3 シーズンにわたり、述べ 107 症例の診療内容・治療 経過を詳細に追跡した。この間、グラム染色の実施割合は $0 \%$ から $22.7 \%$ 、血液培養の 提出は 22\%から 95\%へとそれぞれ経年的に増加し、治療開始時の広域抗菌薬使用は 50\% から $14 \%$ へと減少した。教育体制が変化した直後に加えてその翌年まで測定を続けたと ころ、診療プロセスに生じた変化は持続していた。一方、平均在院日数や死亡割合・医 療費など診療アウトカムには有意な变化は見られず、測定した範囲では治療の変更によ る患者への不利益は認められなかった。

上記診療プロセスの変化と診療アウトカムとの関連は認められなかったが、先行研究 の知見と併せると、多剤而性菌の出現抑制を通じた再発時の予後改善や院内の他の感染 症例における治療の軽減にもつながると推測された。

以上の研究は医師卒後教育体制の充実と肺炎における診療プロセス・診療アウトカム の変化との関連性の解明に貢献し、わが国における感染症診療教育の一層の充実に寄与 するところが多い

したがって、本論文は博士（医学）の学位論文として価值あるものと認める。 なお、本学位授与申請者は、平成 23 年 2 月 7 日実施の論文内容とそれに関連 した試問を受け、合格と認められたものである。 